\title{
PENGUJIAN MULTIMEDIA PEMBELAJARAN MATERI PERKEMBANGBIAKAN HEWAN DAN TUMBUHAN UNTUK SEKOLAH DASAR
}

\author{
Faulinda Ely Nastiti' ${ }^{1}$, Mira Erlinawati ${ }^{2}$ \\ Sistem Informasi, STMIK Duta Bangsa Surakarta \\ Ifaulinda_elyestmikdb.ac.id \\ ${ }^{2}$ mira_erlinawati@stmikdb.ac.id
}

\begin{abstract}
Multimedia learning can be used as a teacher teaching aids, especially to visualize teaching materials. In order to maximum its learning tools, then the implementation of multimedia learning must go through the testing process first. The purpose of this study is to test the functionality of the application and to measure the perceptions of teachers and students on the multimedia learning of animal and plant breeding. Testing is done by Beta testing method consists of two stages: 1) application functionality testing, 2) user perception testing (teacher and student). Tests carried out by the perception of a Likert scale, and processed by taking the mean of the answers. $100 \%$ of the applications can be run in accordance with functionality. Variables: interface, interactions and material on learning multimedia of animal and plant breeding can be accepted by teachers and students. The challenge remains on infrastructure such as a computer student who has not been adequate or even students have not had a computer / tablet at home, so that the self-learning process can not be maximized.
\end{abstract}

\section{Keywords - beta testing, functionalit, multimedia learning,, user perception}

\section{Pendahuluan}

Proses pembelajaran dengan penggunaan teknologi informasi seperti multimedia pembelajaran dapat digunakan untuk mensupport praktik pembelajaran [1] sebagai alat demostrasi guru dalam memvisualisasikan materi ajar [2]. Multimedia learning sebagai alat pedagogis dapat menyelaraskan gaya pengajaran guru dengan gaya belajar siswa [3] yang dapat berperan aktif pada keterlibatan siswa dalam proses pembelajaran.

Teknologi pembelajaran seperti multimedia learning dapat memotivasi siswa untuk belajar. Multimedia Learning mengubah proses pembelajaran lebih menyenangkan [4]. Penggunaan multimedia pembelajaran memungkinkan siswa untuk memperdalam pemahaman mereka tentang sebuah topik [5] mewujudkan tujuan pendidikan dan memudahkan proses pembelajaran [6].

Siswa sekolah dasar memiliki karakteristik belajar pada fakta dan visualisasi berdasarkan multimedia pembelajaran yang digunakan oleh guru [7] Sehubungan dengan kesuksesan implementasi dan penggunaan Multimedia Pembelajaran, maka aplikasi yang dibangun haruslah sesuai dengan perilaku [8] serta kebutuhan siswa [9] dan guru. Dalam upaya meminimalisir resiko kegagalan implementasi multimedia pembelajaran, maka pengujian kesesuaian kebutuhan pengguna perlu dilakukan.

Tujuan dari penelitian ini adalah untuk menguji fungsionalitas aplikasi dan mengukur persepsi guru dan siswa terhadap multimedia pembelajaran reproduksi hewan dan manusia.

\section{Metode Penelitian}

Multimedia Pembelajaran perkembangbiakan Hewan dan Tumbuhan telah penulis kembangkan seperti pada gambar 1 . 


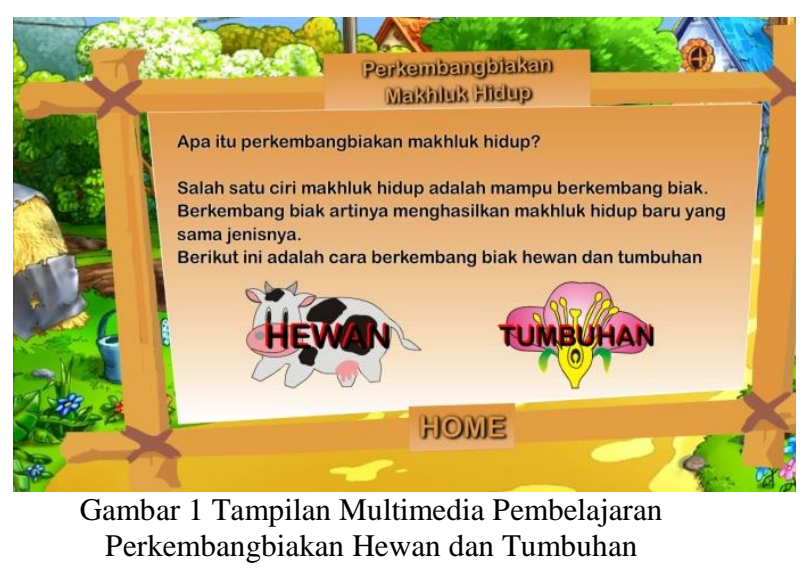

Pengujian dilakukan dengan metode Beta Testing yang melibatkan siswa dan guru Sekolah Dasar Negeri Tegalrejo I Semanggi, Surakarta sebagai pengguna akhir. Pengujian dilakukan dengan beberapa tahapan, yaitu:

Tahap pengujian fungsionalitas multimedia pembelajaran. Pengujian dilakukan dengan memberikan kuisioner tertutup kepada Guru Kelas VII. Pertanyaan mengarah pada keberhasilan aplikasi dalam memproses setiap aksi yang dilakukan guru pada multimedia pembelajaran. Dengan jenis jawaban sesuai atau tidak sesuai.

Tahap pengujian persepsi guru dan siswa terhadap multimedia pembelajaran, dilakukan dengan menyebar kuisioner tertutup menggunakan Skala Likert yang terdiri dari 5 jawaban: sangat tidak setuju bernilai 1 , tidak setuju bernilai 2, kurang setuju bernilai 3, setuju bernilai 4, Sangat Setuju bernilai 5. Kuisioner disebarkan kepada 6 guru, 30 siswa. Kuisioner terdiri dari 4 kriteria pertanyaan yaitu:

1. Tampilan: warna, gambar, animasi, text

2. Interaksi: tombol, navigasi, musik (backsound), doubing materi

3. Materi: relevansi materi, relevansi visualisasi animasi, ketertarikan, pemahaman

4. Infrastruktur: Infrastruktur di sekolah, Insfrastruktur siswa,

Data diolah dengan teknik rerata, menggunakan rentang penilaian:
a. $\quad<1.5=$ Sangat tidak Setuju
b. $\quad 1.6-2.5=$ Tidak Setuju
c. $\quad 2.6-3.5=$ Kurang Setuju
d. $\quad 3.6-4.5=$ Setuju
e. $\quad \geq 4.6=$ Sangat Setuju

\section{HASil Dan Pembahasan}

\section{Pengujian Fungsional}

Pengujian Fungsional dilakukan oleh guru kelas VI dengan skenario dan hasil sebagai berikut:

TABEL 1

Skenario Pengujian Fungsional

\begin{tabular}{|c|c|c|c|}
\hline Scene & $\begin{array}{l}\text { Penguji } \\
\text { an }\end{array}$ & $\begin{array}{l}\text { Hasil yang } \\
\text { diharapka } \\
\text { n }\end{array}$ & $\begin{array}{l}\text { Hasil } \\
\text { yang } \\
\text { didapat }\end{array}$ \\
\hline \multirow[t]{2}{*}{ Intro } & $\begin{array}{l}\text { Tombol } \\
\text { masuk }\end{array}$ & $\begin{array}{l}\text { Pindah ke } \\
\text { scene } \\
\text { menuutama }\end{array}$ & Sesuai \\
\hline & $\begin{array}{l}\text { Animasi } \\
\text { tulisan } \\
\text { judul }\end{array}$ & $\begin{array}{l}\text { Masuk } \\
\text { kedalam } \\
\text { scene } \\
\text { dengan } \\
\text { bounce } \\
\end{array}$ & Sesuai \\
\hline \multirow[t]{7}{*}{ Menuutama } & $\begin{array}{l}\text { Animasi } \\
\text { tombol } \\
\text { menuuta } \\
\text { ma }\end{array}$ & $\begin{array}{l}\text { Keluar } \\
\text { tombol } \\
\text { berupa daun } \\
\text { dari sebuah } \\
\text { pohon }\end{array}$ & Sesuai \\
\hline & $\begin{array}{l}\text { Animasi } \\
\text { tombol } \\
\text { keluar }\end{array}$ & $\begin{array}{l}\text { Lebah } \\
\text { terbang dan } \\
\text { berubah } \\
\text { menjadi } \\
\text { tombol } \\
\text { keluar }\end{array}$ & Sesuai \\
\hline & $\begin{array}{l}\text { Suara } \\
\text { backgro } \\
\text { und }\end{array}$ & $\begin{array}{l}\text { Memutar } \\
\text { suara } \\
\text { background } \\
\text { dengan } \\
\text { volume } \\
\text { penuh }\end{array}$ & Sesuai \\
\hline & $\begin{array}{l}\text { Tombol } \\
\text { materi }\end{array}$ & $\begin{array}{l}\text { Pindah ke } \\
\text { scene materi }\end{array}$ & Sesuai \\
\hline & $\begin{array}{l}\text { Tombol } \\
\text { evaluasi }\end{array}$ & $\begin{array}{ll}\text { Pindah } & \text { ke } \\
\text { scene } & \\
\text { evaluasi } & \\
\end{array}$ & Sesuai \\
\hline & $\begin{array}{l}\text { Tombol } \\
\text { petunjuk }\end{array}$ & $\begin{array}{l}\text { Pindah ke } \\
\text { scene } \\
\text { petunjuk }\end{array}$ & Sesuai \\
\hline & $\begin{array}{l}\text { Tombol } \\
\text { keluar }\end{array}$ & $\begin{array}{l}\text { Aplikasi } \\
\text { berhenti }\end{array}$ & Sesuai \\
\hline \multirow[t]{5}{*}{ Materi } & $\begin{array}{l}\text { Suara } \\
\text { backgro } \\
\text { und }\end{array}$ & $\begin{array}{l}\text { Suara } \\
\text { background } \\
\text { mengecil }\end{array}$ & Sesuai \\
\hline & $\begin{array}{l}\text { Suara } \\
\text { materi }\end{array}$ & $\begin{array}{l}\text { Memutar } \\
\text { suara materi }\end{array}$ & Sesuai \\
\hline & $\begin{array}{l}\text { Teks } \\
\text { penjelas } \\
\text { an } \\
\text { materi } \\
\end{array}$ & $\begin{array}{l}\text { Muncul teks } \\
\text { penjelasan } \\
\text { materi }\end{array}$ & Sesuai \\
\hline & $\begin{array}{l}\text { Tombol } \\
\text { hewan }\end{array}$ & $\begin{array}{l}\text { Pindah ke } \\
\text { scene hewan }\end{array}$ & Sesuai \\
\hline & $\begin{array}{l}\text { Tombol } \\
\text { tumbuha } \\
\mathrm{n}\end{array}$ & $\begin{array}{l}\text { Pindah ke } \\
\text { scene } \\
\text { tumbuhan }\end{array}$ & Sesuai \\
\hline
\end{tabular}




\begin{tabular}{|c|c|c|c|}
\hline & $\begin{array}{l}\text { Tombol } \\
\text { home }\end{array}$ & $\begin{array}{l}\text { Pindah ke } \\
\text { scene } \\
\text { menuutama }\end{array}$ & Sesuai \\
\hline \multirow[t]{6}{*}{ Hewan } & $\begin{array}{l}\text { Suara } \\
\text { materi }\end{array}$ & $\begin{array}{l}\text { Memutar } \\
\text { suara materi }\end{array}$ & Sesuai \\
\hline & $\begin{array}{l}\text { Teks } \\
\text { penjelas } \\
\text { an } \\
\text { materi }\end{array}$ & $\begin{array}{l}\text { Muncul teks } \\
\text { penjelasan } \\
\text { materi }\end{array}$ & Sesuai \\
\hline & $\begin{array}{l}\text { Tombol } \\
\text { generati } \\
\text { f }\end{array}$ & $\begin{array}{l}\text { Pindah ke } \\
\text { scene } \\
\text { hgeneratif }\end{array}$ & Sesuai \\
\hline & $\begin{array}{l}\text { Tombol } \\
\text { vegetatif }\end{array}$ & $\begin{array}{l}\text { Pindah ke } \\
\text { scene } \\
\text { hvegetatif }\end{array}$ & Sesuai \\
\hline & $\begin{array}{l}\text { Tombol } \\
\mathrm{X}\end{array}$ & $\begin{array}{l}\text { Pindah ke } \\
\text { scene materi }\end{array}$ & Sesuai \\
\hline & $\begin{array}{l}\text { Tombol } \\
\text { home }\end{array}$ & $\begin{array}{l}\text { Pindah ke } \\
\text { scene } \\
\text { menuutama }\end{array}$ & Sesuai \\
\hline \multirow[t]{7}{*}{ Tumbuhan } & $\begin{array}{l}\text { Suara } \\
\text { materi }\end{array}$ & $\begin{array}{l}\text { Memutar } \\
\text { suara materi }\end{array}$ & Sesuai \\
\hline & $\begin{array}{l}\text { Teks } \\
\text { penjelas } \\
\text { an } \\
\text { materi }\end{array}$ & $\begin{array}{l}\text { Muncul teks } \\
\text { penjelasan } \\
\text { materi }\end{array}$ & Sesuai \\
\hline & $\begin{array}{l}\text { Tombol } \\
\text { generati } \\
\mathrm{f}\end{array}$ & $\begin{array}{l}\text { Pindah ke } \\
\text { scene } \\
\text { tgeneratif }\end{array}$ & Sesuai \\
\hline & $\begin{array}{l}\text { Tombol } \\
\text { vegetatif } \\
\text { alami }\end{array}$ & $\begin{array}{l}\text { Pindah ke } \\
\text { scene } \\
\text { tvalami }\end{array}$ & Sesuai \\
\hline & $\begin{array}{l}\text { Tombol } \\
\text { vegetati } \\
\text { ve } \\
\text { buatan }\end{array}$ & $\begin{array}{l}\text { Pindah ke } \\
\text { scene } \\
\text { tvbuatan }\end{array}$ & Sesuai \\
\hline & $\begin{array}{l}\text { Tombol } \\
\text { home }\end{array}$ & $\begin{array}{l}\text { Pindah ke } \\
\text { scene } \\
\text { menuutama }\end{array}$ & Sesuai \\
\hline & $\begin{array}{l}\text { Tombol } \\
\mathrm{X}\end{array}$ & $\begin{array}{l}\text { Pindah ke } \\
\text { scene materi }\end{array}$ & Sesuai \\
\hline \multirow[t]{7}{*}{$\begin{array}{l}\text { Hgeneratif, } \\
\text { frame } 1\end{array}$} & $\begin{array}{l}\text { Suara } \\
\text { materi }\end{array}$ & $\begin{array}{l}\text { Memutar } \\
\text { suara materi }\end{array}$ & Sesuai \\
\hline & $\begin{array}{l}\text { Teks } \\
\text { penjelas } \\
\text { an } \\
\text { materi }\end{array}$ & $\begin{array}{l}\text { Muncul teks } \\
\text { penjelasan } \\
\text { materi }\end{array}$ & Sesuai \\
\hline & $\begin{array}{l}\text { Animasi } \\
\text { materi }\end{array}$ & $\begin{array}{l}\text { Muncul } \\
\text { animasi } \\
\text { materi }\end{array}$ & Sesuai \\
\hline & $\begin{array}{l}\text { Tombol } \\
\text { next }\end{array}$ & $\begin{array}{l}\text { Pindah ke } \\
\text { Frame } \\
\text { slanjutnya }\end{array}$ & Sesuai \\
\hline & $\begin{array}{l}\text { Tombol } \\
\text { prev }\end{array}$ & $\begin{array}{l}\text { Pindah ke } \\
\text { Frame } \\
\text { sebelumnya }\end{array}$ & Sesuai \\
\hline & $\begin{array}{l}\text { Tombol } \\
\text { home }\end{array}$ & $\begin{array}{l}\text { Pindah ke } \\
\text { scene } \\
\text { menuutama }\end{array}$ & Sesuai \\
\hline & $\begin{array}{l}\text { Tombol } \\
\mathrm{X}\end{array}$ & $\begin{array}{l}\text { Pindah ke } \\
\text { scene hewan }\end{array}$ & Sesuai \\
\hline $\begin{array}{l}\text { Hgeneratif, } \\
\text { frame } 2\end{array}$ & $\begin{array}{l}\text { Suara } \\
\text { materi }\end{array}$ & $\begin{array}{l}\text { Memutar } \\
\text { suara materi }\end{array}$ & Sesuai \\
\hline
\end{tabular}

\begin{tabular}{|c|c|c|c|}
\hline & $\begin{array}{l}\text { Teks } \\
\text { penjelas } \\
\text { an } \\
\text { materi }\end{array}$ & $\begin{array}{l}\text { Muncul teks } \\
\text { penjelasan } \\
\text { materi }\end{array}$ & Sesuai \\
\hline & $\begin{array}{l}\text { Animasi } \\
\text { materi }\end{array}$ & $\begin{array}{l}\text { Muncul } \\
\text { animasi } \\
\text { materi }\end{array}$ & Sesuai \\
\hline & $\begin{array}{l}\text { Tombol } \\
\text { next }\end{array}$ & $\begin{array}{l}\text { Pindah ke } \\
\text { Frame } \\
\text { slanjutnya }\end{array}$ & Sesuai \\
\hline & $\begin{array}{l}\text { Tombol } \\
\text { prev }\end{array}$ & $\begin{array}{l}\text { Pindah ke } \\
\text { Frame } \\
\text { sebelumnya }\end{array}$ & Sesuai \\
\hline & $\begin{array}{l}\text { Tombol } \\
\text { home }\end{array}$ & $\begin{array}{l}\text { Pindah ke } \\
\text { scene } \\
\text { menuutama }\end{array}$ & Sesuai \\
\hline & $\begin{array}{l}\text { Tombol } \\
\mathrm{X}\end{array}$ & $\begin{array}{l}\text { Pindah ke } \\
\text { scene hewan }\end{array}$ & Sesuai \\
\hline \multirow[t]{7}{*}{$\begin{array}{l}\text { Hgeneratif, } \\
\text { frame } 3\end{array}$} & $\begin{array}{l}\text { Suara } \\
\text { materi }\end{array}$ & $\begin{array}{l}\text { Memutar } \\
\text { suara materi }\end{array}$ & Sesuai \\
\hline & $\begin{array}{l}\text { Teks } \\
\text { penjelas } \\
\text { an } \\
\text { materi }\end{array}$ & $\begin{array}{l}\text { Muncul teks } \\
\text { penjelasan } \\
\text { materi }\end{array}$ & Sesuai \\
\hline & $\begin{array}{l}\text { Animasi } \\
\text { materi }\end{array}$ & $\begin{array}{l}\text { Muncul } \\
\text { animasi } \\
\text { materi }\end{array}$ & Sesuai \\
\hline & $\begin{array}{l}\text { Tombol } \\
\text { next }\end{array}$ & $\begin{array}{l}\text { Pindah ke } \\
\text { Frame } \\
\text { slanjutnya }\end{array}$ & Sesuai \\
\hline & $\begin{array}{l}\text { Tombol } \\
\text { prev }\end{array}$ & $\begin{array}{l}\text { Pindah ke } \\
\text { Frame } \\
\text { sebelumnya }\end{array}$ & Sesuai \\
\hline & $\begin{array}{l}\text { Tombol } \\
\text { home }\end{array}$ & $\begin{array}{l}\text { Pindah ke } \\
\text { scene } \\
\text { menuutama }\end{array}$ & Sesuai \\
\hline & $\begin{array}{l}\text { Tombol } \\
\mathrm{X}\end{array}$ & $\begin{array}{l}\text { Pindah ke } \\
\text { scene hewan }\end{array}$ & Sesuai \\
\hline \multirow[t]{7}{*}{$\begin{array}{l}\text { Hvegetatif, } \\
\text { frame } 1\end{array}$} & $\begin{array}{l}\text { Suara } \\
\text { materi }\end{array}$ & $\begin{array}{l}\text { Memutar } \\
\text { suara materi }\end{array}$ & Sesuai \\
\hline & $\begin{array}{l}\text { Animasi } \\
\text { materi }\end{array}$ & $\begin{array}{l}\text { Muncul } \\
\text { animasi } \\
\text { materi }\end{array}$ & Sesuai \\
\hline & $\begin{array}{l}\text { Teks } \\
\text { penjelas } \\
\text { an } \\
\text { materi }\end{array}$ & $\begin{array}{l}\text { Muncul teks } \\
\text { penjelasan } \\
\text { materi }\end{array}$ & Sesuai \\
\hline & $\begin{array}{l}\text { Tombol } \\
\text { home }\end{array}$ & $\begin{array}{l}\text { Pindah ke } \\
\text { scene } \\
\text { menuutama }\end{array}$ & Sesuai \\
\hline & $\begin{array}{l}\text { Tombol } \\
\mathrm{X}\end{array}$ & $\begin{array}{l}\text { Pindah ke } \\
\text { scene hewan }\end{array}$ & Sesuai \\
\hline & $\begin{array}{l}\text { Tombol } \\
\text { next }\end{array}$ & $\begin{array}{l}\text { Pindah ke } \\
\text { Frame } \\
\text { selanjutnya }\end{array}$ & Sesuai \\
\hline & $\begin{array}{l}\text { Tombol } \\
\text { prev }\end{array}$ & $\begin{array}{l}\text { Pindah ke } \\
\text { Frame } \\
\text { sebelumnya }\end{array}$ & Sesuai \\
\hline \multirow[t]{2}{*}{$\begin{array}{l}\text { Hvegetatif, } \\
\text { frame } 2\end{array}$} & $\begin{array}{l}\text { Suara } \\
\text { materi }\end{array}$ & $\begin{array}{l}\text { Memutar } \\
\text { suara materi }\end{array}$ & Sesuai \\
\hline & $\begin{array}{l}\text { Animasi } \\
\text { materi }\end{array}$ & $\begin{array}{l}\text { Muncul } \\
\text { animasi } \\
\text { materi }\end{array}$ & Sesuai \\
\hline
\end{tabular}




\begin{tabular}{|c|c|c|c|}
\hline & $\begin{array}{l}\text { Teks } \\
\text { penjelas } \\
\text { an } \\
\text { materi }\end{array}$ & $\begin{array}{l}\text { Muncul teks } \\
\text { penjelasan } \\
\text { materi }\end{array}$ & Sesuai \\
\hline & $\begin{array}{l}\text { Tombol } \\
\text { home }\end{array}$ & $\begin{array}{l}\text { Pindah ke } \\
\text { scene } \\
\text { menuutama }\end{array}$ & Sesuai \\
\hline & $\begin{array}{l}\text { Tombol } \\
\mathrm{X}\end{array}$ & $\begin{array}{l}\text { Pindah ke } \\
\text { scene hewan }\end{array}$ & Sesuai \\
\hline & $\begin{array}{l}\text { Tombol } \\
\text { next }\end{array}$ & $\begin{array}{l}\text { Pindah ke } \\
\text { Frame } \\
\text { selanjutnya }\end{array}$ & Sesuai \\
\hline & $\begin{array}{l}\text { Tombol } \\
\text { prev }\end{array}$ & $\begin{array}{l}\text { Pindah ke } \\
\text { Frame } \\
\text { sebelumnya }\end{array}$ & Sesuai \\
\hline \multirow[t]{7}{*}{$\begin{array}{l}\text { Tgeneratif, } \\
\text { frame } 1\end{array}$} & $\begin{array}{l}\text { Suara } \\
\text { materi }\end{array}$ & $\begin{array}{l}\text { Memutar } \\
\text { suara materi }\end{array}$ & Sesuai \\
\hline & $\begin{array}{l}\text { Teks } \\
\text { penjelas } \\
\text { an } \\
\text { materi }\end{array}$ & $\begin{array}{l}\text { Muncul teks } \\
\text { penjelasan } \\
\text { materi }\end{array}$ & Sesuai \\
\hline & $\begin{array}{l}\text { Animasi } \\
\text { materi }\end{array}$ & $\begin{array}{l}\text { Muncul } \\
\text { animasi } \\
\text { materi } \\
\end{array}$ & Sesuai \\
\hline & $\begin{array}{l}\text { Tombol } \\
\text { Home }\end{array}$ & $\begin{array}{l}\text { Pindah ke } \\
\text { scene } \\
\text { menuutama }\end{array}$ & Sesuai \\
\hline & $\begin{array}{l}\text { Tombol } \\
\mathrm{X}\end{array}$ & $\begin{array}{l}\text { Pindah ke } \\
\text { scene } \\
\text { tumbuhan }\end{array}$ & Sesuai \\
\hline & $\begin{array}{l}\text { Tombol } \\
\text { Next }\end{array}$ & $\begin{array}{l}\text { Pindah ke } \\
\text { Frame } \\
\text { selanjutnya }\end{array}$ & Sesuai \\
\hline & $\begin{array}{l}\text { Tombol } \\
\text { prev }\end{array}$ & $\begin{array}{l}\text { Pindah ke } \\
\text { Frame } \\
\text { sebelumnya }\end{array}$ & Sesuai \\
\hline \multirow[t]{7}{*}{$\begin{array}{l}\text { Tgeneratif, } \\
\text { frame } 2\end{array}$} & $\begin{array}{l}\text { Suara } \\
\text { materi }\end{array}$ & $\begin{array}{l}\text { Memutar } \\
\text { suara materi }\end{array}$ & Sesuai \\
\hline & $\begin{array}{l}\text { Teks } \\
\text { penjelas } \\
\text { an } \\
\text { materi }\end{array}$ & $\begin{array}{l}\text { Muncul teks } \\
\text { penjelasan } \\
\text { materi }\end{array}$ & Sesuai \\
\hline & $\begin{array}{l}\text { Animasi } \\
\text { materi }\end{array}$ & $\begin{array}{l}\text { Muncul } \\
\text { animasi } \\
\text { materi }\end{array}$ & Sesuai \\
\hline & $\begin{array}{l}\text { Tombol } \\
\text { Home }\end{array}$ & $\begin{array}{l}\text { Pindah ke } \\
\text { scene } \\
\text { menuutama }\end{array}$ & Sesuai \\
\hline & $\begin{array}{l}\text { Tombol } \\
\mathrm{X}\end{array}$ & $\begin{array}{l}\text { Pindah ke } \\
\text { scene } \\
\text { tumbuhan }\end{array}$ & Sesuai \\
\hline & $\begin{array}{l}\text { Tombol } \\
\text { Next }\end{array}$ & $\begin{array}{l}\text { Pindah ke } \\
\text { Frame } \\
\text { selanjutnya }\end{array}$ & Sesuai \\
\hline & $\begin{array}{l}\text { Tombol } \\
\text { prev }\end{array}$ & $\begin{array}{l}\text { Pindah ke } \\
\text { Frame } \\
\text { sebelumnya }\end{array}$ & Sesuai \\
\hline \multirow[t]{2}{*}{$\begin{array}{l}\text { Tgeneratif, } \\
\text { frame } 3\end{array}$} & $\begin{array}{l}\text { Suara } \\
\text { materi }\end{array}$ & $\begin{array}{l}\text { Memutar } \\
\text { suara materi }\end{array}$ & Sesuai \\
\hline & $\begin{array}{l}\text { Teks } \\
\text { penjelas } \\
\text { an } \\
\text { materi }\end{array}$ & $\begin{array}{l}\text { Muncul teks } \\
\text { penjelasan } \\
\text { materi }\end{array}$ & Sesuai \\
\hline
\end{tabular}

\begin{tabular}{|c|c|c|c|}
\hline & $\begin{array}{l}\text { Animasi } \\
\text { materi }\end{array}$ & $\begin{array}{l}\text { Muncul } \\
\text { animasi } \\
\text { materi }\end{array}$ & Sesuai \\
\hline & $\begin{array}{l}\text { Tombol } \\
\text { Home }\end{array}$ & $\begin{array}{l}\text { Pindah ke } \\
\text { scene } \\
\text { menuutama }\end{array}$ & Sesuai \\
\hline & $\begin{array}{l}\text { Tombol } \\
\mathrm{X}\end{array}$ & $\begin{array}{l}\text { Pindah ke } \\
\text { scene } \\
\text { tumbuhan }\end{array}$ & Sesuai \\
\hline & $\begin{array}{l}\text { Tombol } \\
\text { Next }\end{array}$ & $\begin{array}{l}\text { Pindah ke } \\
\text { Frame } \\
\text { selanjutnya }\end{array}$ & Sesuai \\
\hline & $\begin{array}{l}\text { Tombol } \\
\text { prev }\end{array}$ & $\begin{array}{l}\text { Pindah ke } \\
\text { Frame } \\
\text { sebelumnya }\end{array}$ & Sesuai \\
\hline \multirow[t]{7}{*}{$\begin{array}{l}\text { Tgeneratif, } \\
\text { frame } 4\end{array}$} & $\begin{array}{l}\text { Suara } \\
\text { materi }\end{array}$ & $\begin{array}{l}\text { Memutar } \\
\text { suara materi }\end{array}$ & Sesuai \\
\hline & $\begin{array}{l}\text { Teks } \\
\text { penjelas } \\
\text { an } \\
\text { materi }\end{array}$ & $\begin{array}{l}\text { Muncul teks } \\
\text { penjelasan } \\
\text { materi }\end{array}$ & Sesuai \\
\hline & $\begin{array}{l}\text { Animasi } \\
\text { materi }\end{array}$ & $\begin{array}{l}\text { Muncul } \\
\text { animasi } \\
\text { materi }\end{array}$ & Sesuai \\
\hline & $\begin{array}{l}\text { Tombol } \\
\text { Home }\end{array}$ & $\begin{array}{l}\text { Pindah ke } \\
\text { scene } \\
\text { menuutama }\end{array}$ & Sesuai \\
\hline & $\begin{array}{l}\text { Tombol } \\
\mathrm{X}\end{array}$ & $\begin{array}{l}\text { Pindah ke } \\
\text { scene } \\
\text { tumbuhan }\end{array}$ & Sesuai \\
\hline & $\begin{array}{l}\text { Tombol } \\
\text { Next }\end{array}$ & $\begin{array}{l}\text { Pindah ke } \\
\text { Frame } \\
\text { selanjutnya }\end{array}$ & Sesuai \\
\hline & $\begin{array}{l}\text { Tombol } \\
\text { prev }\end{array}$ & $\begin{array}{l}\text { Pindah ke } \\
\text { Frame } \\
\text { sebelumnya }\end{array}$ & Sesuai \\
\hline \multirow[t]{7}{*}{$\begin{array}{l}\text { Tvalami, } \\
\text { frame } 1\end{array}$} & $\begin{array}{l}\text { Suara } \\
\text { materi }\end{array}$ & $\begin{array}{l}\text { Memutar } \\
\text { suara materi }\end{array}$ & Sesuai \\
\hline & $\begin{array}{l}\text { Teks } \\
\text { penjelas } \\
\text { an } \\
\text { materi }\end{array}$ & $\begin{array}{l}\text { Muncul teks } \\
\text { penjelasan } \\
\text { materi }\end{array}$ & Sesuai \\
\hline & $\begin{array}{l}\text { Animasi } \\
\text { materi }\end{array}$ & $\begin{array}{l}\text { Muncul } \\
\text { animasi } \\
\text { materi }\end{array}$ & Sesuai \\
\hline & $\begin{array}{l}\text { Tombol } \\
\text { Home }\end{array}$ & $\begin{array}{l}\text { Pindah ke } \\
\text { scene } \\
\text { menuutama }\end{array}$ & Sesuai \\
\hline & $\begin{array}{l}\text { Tombol } \\
\mathrm{X}\end{array}$ & $\begin{array}{l}\text { Pindah ke } \\
\text { scene } \\
\text { tumbuhan }\end{array}$ & Sesuai \\
\hline & $\begin{array}{l}\text { Tombol } \\
\text { next }\end{array}$ & $\begin{array}{l}\text { Pindah ke } \\
\text { Frame } \\
\text { selanjutnya }\end{array}$ & Sesuai \\
\hline & $\begin{array}{l}\text { Tombol } \\
\text { prev }\end{array}$ & $\begin{array}{l}\text { Pindah ke } \\
\text { Frame } \\
\text { sebelumnya }\end{array}$ & Sesuai \\
\hline \multirow[t]{2}{*}{$\begin{array}{l}\text { Tvalami, } \\
\text { frame } 2\end{array}$} & $\begin{array}{l}\text { Suara } \\
\text { materi }\end{array}$ & $\begin{array}{l}\text { Memutar } \\
\text { suara materi }\end{array}$ & Sesuai \\
\hline & $\begin{array}{l}\text { Teks } \\
\text { penjelas } \\
\text { an } \\
\text { materi }\end{array}$ & $\begin{array}{l}\text { Muncul teks } \\
\text { penjelasan } \\
\text { materi }\end{array}$ & Sesuai \\
\hline
\end{tabular}


Jurnal Teknologi Informatika dan Terapan Vol. 04, No 02, Juli - Desember 2017

\begin{tabular}{|c|c|c|c|}
\hline & $\begin{array}{l}\text { Animasi } \\
\text { materi }\end{array}$ & $\begin{array}{l}\text { Muncul } \\
\text { animasi } \\
\text { materi }\end{array}$ & Sesuai \\
\hline & $\begin{array}{l}\text { Tombol } \\
\text { Home }\end{array}$ & $\begin{array}{l}\text { Pindah ke } \\
\text { scene } \\
\text { menuutama }\end{array}$ & Sesuai \\
\hline & $\begin{array}{l}\text { Tombol } \\
\mathrm{X}\end{array}$ & $\begin{array}{l}\text { Pindah ke } \\
\text { scene } \\
\text { tumbuhan }\end{array}$ & Sesuai \\
\hline & $\begin{array}{l}\text { Tombol } \\
\text { next }\end{array}$ & $\begin{array}{l}\text { Pindah ke } \\
\text { Frame } \\
\text { selanjutnya }\end{array}$ & Sesuai \\
\hline & $\begin{array}{l}\text { Tombol } \\
\text { prev }\end{array}$ & $\begin{array}{l}\text { Pindah ke } \\
\text { Frame } \\
\text { sebelumnya }\end{array}$ & Sesuai \\
\hline \multirow[t]{7}{*}{$\begin{array}{l}\text { Tvalami, } \\
\text { frame } 3\end{array}$} & $\begin{array}{l}\text { Suara } \\
\text { materi }\end{array}$ & $\begin{array}{l}\text { Memutar } \\
\text { suara materi }\end{array}$ & Sesuai \\
\hline & $\begin{array}{l}\text { Teks } \\
\text { penjelas } \\
\text { an } \\
\text { materi }\end{array}$ & $\begin{array}{l}\text { Muncul teks } \\
\text { penjelasan } \\
\text { materi }\end{array}$ & Sesuai \\
\hline & $\begin{array}{l}\text { Animasi } \\
\text { materi }\end{array}$ & $\begin{array}{l}\text { Muncul } \\
\text { animasi } \\
\text { materi }\end{array}$ & Sesuai \\
\hline & $\begin{array}{l}\text { Tombol } \\
\text { Home }\end{array}$ & $\begin{array}{l}\text { Pindah ke } \\
\text { scene } \\
\text { menuutama }\end{array}$ & Sesuai \\
\hline & $\begin{array}{l}\text { Tombol } \\
\mathrm{X}\end{array}$ & $\begin{array}{l}\text { Pindah ke } \\
\text { scene } \\
\text { tumbuhan }\end{array}$ & Sesuai \\
\hline & $\begin{array}{l}\text { Tombol } \\
\text { next }\end{array}$ & $\begin{array}{l}\text { Pindah ke } \\
\text { Frame } \\
\text { selanjutnya }\end{array}$ & Sesuai \\
\hline & $\begin{array}{l}\text { Tombol } \\
\text { prev }\end{array}$ & $\begin{array}{l}\text { Pindah ke } \\
\text { Frame } \\
\text { sebelumnya }\end{array}$ & Sesuai \\
\hline \multirow[t]{7}{*}{$\begin{array}{l}\text { Tvalami, } \\
\text { frame } 4\end{array}$} & $\begin{array}{l}\text { Suara } \\
\text { materi }\end{array}$ & $\begin{array}{l}\text { Memutar } \\
\text { suara materi }\end{array}$ & Sesuai \\
\hline & $\begin{array}{l}\text { Teks } \\
\text { penjelas } \\
\text { an } \\
\text { materi }\end{array}$ & $\begin{array}{l}\text { Muncul teks } \\
\text { penjelasan } \\
\text { materi }\end{array}$ & Sesuai \\
\hline & $\begin{array}{l}\text { Animasi } \\
\text { materi }\end{array}$ & $\begin{array}{l}\text { Muncul } \\
\text { animasi } \\
\text { materi }\end{array}$ & Sesuai \\
\hline & $\begin{array}{l}\text { Tombol } \\
\text { Home }\end{array}$ & $\begin{array}{l}\text { Pindah ke } \\
\text { scene } \\
\text { menuutama }\end{array}$ & Sesuai \\
\hline & $\begin{array}{l}\text { Tombol } \\
\mathrm{X}\end{array}$ & $\begin{array}{l}\text { Pindah ke } \\
\text { scene } \\
\text { tumbuhan }\end{array}$ & Sesuai \\
\hline & $\begin{array}{l}\text { Tombol } \\
\text { next }\end{array}$ & $\begin{array}{l}\text { Pindah ke } \\
\text { Frame } \\
\text { selanjutnya }\end{array}$ & Sesuai \\
\hline & $\begin{array}{l}\text { Tombol } \\
\text { prev }\end{array}$ & $\begin{array}{l}\text { Pindah ke } \\
\text { Frame } \\
\text { sebelumnya }\end{array}$ & Sesuai \\
\hline \multirow[t]{2}{*}{$\begin{array}{l}\text { Tvalami, } \\
\text { frame } 5\end{array}$} & $\begin{array}{l}\text { Suara } \\
\text { materi }\end{array}$ & $\begin{array}{l}\text { Memutar } \\
\text { suara materi }\end{array}$ & Sesuai \\
\hline & $\begin{array}{l}\text { Teks } \\
\text { penjelas } \\
\text { an } \\
\text { materi }\end{array}$ & $\begin{array}{l}\text { Muncul teks } \\
\text { penjelasan } \\
\text { materi }\end{array}$ & Sesuai \\
\hline
\end{tabular}

\begin{tabular}{|c|c|c|c|}
\hline & $\begin{array}{l}\text { Animasi } \\
\text { materi }\end{array}$ & $\begin{array}{l}\text { Muncul } \\
\text { animasi } \\
\text { materi }\end{array}$ & Sesuai \\
\hline & $\begin{array}{l}\text { Tombol } \\
\text { Home }\end{array}$ & $\begin{array}{l}\text { Pindah ke } \\
\text { scene } \\
\text { menuutama }\end{array}$ & Sesuai \\
\hline & $\begin{array}{l}\text { Tombol } \\
\mathrm{X}\end{array}$ & $\begin{array}{l}\text { Pindah ke } \\
\text { scene } \\
\text { tumbuhan }\end{array}$ & Sesuai \\
\hline & $\begin{array}{l}\text { Tombol } \\
\text { next }\end{array}$ & $\begin{array}{l}\text { Pindah ke } \\
\text { Frame } \\
\text { selanjutnya }\end{array}$ & Sesuai \\
\hline & $\begin{array}{l}\text { Tombol } \\
\text { prev }\end{array}$ & $\begin{array}{l}\text { Pindah ke } \\
\text { Frame } \\
\text { sebelumnya }\end{array}$ & Sesuai \\
\hline \multirow[t]{7}{*}{$\begin{array}{l}\text { Tvbuatan, } \\
\text { frame } 1\end{array}$} & $\begin{array}{l}\text { Suara } \\
\text { materi }\end{array}$ & $\begin{array}{l}\text { Memutar } \\
\text { suara materi }\end{array}$ & Sesuai \\
\hline & $\begin{array}{l}\text { Teks } \\
\text { penjelas } \\
\text { an } \\
\text { materi }\end{array}$ & $\begin{array}{l}\text { Muncul teks } \\
\text { penjelasan } \\
\text { materi }\end{array}$ & Sesuai \\
\hline & $\begin{array}{l}\text { Animasi } \\
\text { materi }\end{array}$ & $\begin{array}{l}\text { Muncul } \\
\text { animasi } \\
\text { materi }\end{array}$ & Sesuai \\
\hline & $\begin{array}{l}\text { Tombol } \\
\text { home }\end{array}$ & $\begin{array}{l}\text { Pindah ke } \\
\text { scene } \\
\text { menuutama }\end{array}$ & Sesuai \\
\hline & $\begin{array}{l}\text { Tombol } \\
\mathrm{X}\end{array}$ & $\begin{array}{l}\text { Pindah ke } \\
\text { scene } \\
\text { tumbuhan }\end{array}$ & Sesuai \\
\hline & Tombol & $\begin{array}{l}\text { Pindah ke } \\
\text { Frame } \\
\text { selanjutnya }\end{array}$ & Sesuai \\
\hline & $\begin{array}{l}\text { Tombol } \\
\text { prev }\end{array}$ & $\begin{array}{l}\text { Pindah ke } \\
\text { Frame } \\
\text { sebelumnya }\end{array}$ & Sesuai \\
\hline \multirow[t]{7}{*}{$\begin{array}{l}\text { Tvbuatan, } \\
\text { frame } 2\end{array}$} & $\begin{array}{l}\text { Suara } \\
\text { materi }\end{array}$ & $\begin{array}{l}\text { Memutar } \\
\text { suara materi }\end{array}$ & Sesuai \\
\hline & $\begin{array}{l}\text { Teks } \\
\text { penjelas } \\
\text { an } \\
\text { materi }\end{array}$ & $\begin{array}{l}\text { Muncul teks } \\
\text { penjelasan } \\
\text { materi }\end{array}$ & Sesuai \\
\hline & $\begin{array}{l}\text { Animasi } \\
\text { materi }\end{array}$ & $\begin{array}{l}\text { Muncul } \\
\text { animasi } \\
\text { materi }\end{array}$ & Sesuai \\
\hline & $\begin{array}{l}\text { Tombol } \\
\text { home }\end{array}$ & $\begin{array}{l}\text { Pindah ke } \\
\text { scene } \\
\text { menuutama }\end{array}$ & Sesuai \\
\hline & $\begin{array}{l}\text { Tombol } \\
\mathrm{X}\end{array}$ & $\begin{array}{l}\text { Pindah ke } \\
\text { scene } \\
\text { tumbuhan }\end{array}$ & Sesuai \\
\hline & $\begin{array}{l}\text { Tombol } \\
\text { next }\end{array}$ & $\begin{array}{l}\text { Pindah ke } \\
\text { Frame } \\
\text { selanjutnya }\end{array}$ & Sesuai \\
\hline & $\begin{array}{l}\text { Tombol } \\
\text { prev }\end{array}$ & $\begin{array}{l}\text { Pindah ke } \\
\text { Frame } \\
\text { sebelumnya }\end{array}$ & Sesuai \\
\hline \multirow[t]{2}{*}{$\begin{array}{l}\text { Tvbuatan, } \\
\text { frame } 3\end{array}$} & $\begin{array}{l}\text { Suara } \\
\text { materi }\end{array}$ & $\begin{array}{l}\text { Memutar } \\
\text { suara materi }\end{array}$ & Sesuai \\
\hline & $\begin{array}{l}\text { Teks } \\
\text { penjelas } \\
\text { an } \\
\text { materi }\end{array}$ & $\begin{array}{l}\text { Muncul teks } \\
\text { penjelasan } \\
\text { materi }\end{array}$ & Sesuai \\
\hline
\end{tabular}




\begin{tabular}{|c|c|c|c|}
\hline & $\begin{array}{l}\text { Animasi } \\
\text { materi }\end{array}$ & $\begin{array}{l}\text { Muncul } \\
\text { animasi } \\
\text { materi }\end{array}$ & Sesuai \\
\hline & $\begin{array}{l}\text { Tombol } \\
\text { home }\end{array}$ & $\begin{array}{l}\text { Pindah ke } \\
\text { scene } \\
\text { menuutama }\end{array}$ & Sesuai \\
\hline & $\begin{array}{l}\text { Tombol } \\
\mathrm{X}\end{array}$ & $\begin{array}{l}\text { Pindah ke } \\
\text { scene } \\
\text { tumbuhan }\end{array}$ & Sesuai \\
\hline & Tombol & $\begin{array}{l}\text { Pindah ke } \\
\text { Frame } \\
\text { selanjutnya }\end{array}$ & Sesuai \\
\hline & $\begin{array}{l}\text { Tombol } \\
\text { prev }\end{array}$ & $\begin{array}{l}\text { Pindah ke } \\
\text { Frame } \\
\text { sebelumnya }\end{array}$ & Sesuai \\
\hline \multirow[t]{2}{*}{ Petunjuk } & $\begin{array}{l}\text { Tombol } \\
\text { home }\end{array}$ & $\begin{array}{l}\text { Pindah ke } \\
\text { scene } \\
\text { menuutama }\end{array}$ & Sesuai \\
\hline & $\begin{array}{l}\text { Teks } \\
\text { penjelas } \\
\text { an } \\
\text { penggun } \\
\text { aan }\end{array}$ & $\begin{array}{l}\text { Muncul teks } \\
\text { penjelasan } \\
\text { penggunaan }\end{array}$ & Sesuai \\
\hline \multirow[t]{8}{*}{ Evaluasi } & $\begin{array}{l}\text { Tombol } \\
\text { home }\end{array}$ & $\begin{array}{l}\text { Pindah ke } \\
\text { scene } \\
\text { menuutama }\end{array}$ & Sesuai \\
\hline & $\begin{array}{l}\text { Tombol } \\
\text { mulai }\end{array}$ & $\begin{array}{l}\text { Memulai } \\
\text { Frame kuis }\end{array}$ & Sesuai \\
\hline & $\begin{array}{l}\text { Tombol } \\
\text { ulang }\end{array}$ & $\begin{array}{lr}\text { Pindah } & \text { ke } \\
\text { Frame } & 1 \\
\text { scene } & \\
\text { evaluasi } & \\
\end{array}$ & Sesuai \\
\hline & $\begin{array}{l}\text { Soal } \\
\text { pilihan } \\
\text { ganda }\end{array}$ & $\begin{array}{l}\text { Berjumlah } \\
10\end{array}$ & Sesuai \\
\hline & $\begin{array}{l}\text { Soal } \\
\text { isian }\end{array}$ & Berjumlah 5 & Sesuai \\
\hline & $\begin{array}{l}\text { Jawaban } \\
\text { pilihan } \\
\text { ganda }\end{array}$ & $\begin{array}{l}4 \text { pilihan } \\
\text { jawaban } \\
\text { disetiap soal } \\
\text { pilihan } \\
\text { ganda } \\
\end{array}$ & Sesuai \\
\hline & $\begin{array}{l}\text { Jawaban } \\
\text { isian }\end{array}$ & $\begin{array}{l}\text { Terdapat } \\
\text { tempat } \\
\text { untuk } \\
\text { mengisikan } \\
\text { jawaban }\end{array}$ & Sesuai \\
\hline & Skor & $\begin{array}{l}\text { Muncul } \\
\text { tampilan } \\
\text { skor diakhir } \\
\text { evaluasi }\end{array}$ & Sesuai \\
\hline
\end{tabular}

Berdasarkan uji fungsionalitas dapat dilihat bahwa aplikasi dapat berjalan sesuai dengan instruksi dari penggunanya. Aplikasi 100\% dapat berjalan dengan baik pada perangkat komputer yang dimiliki sekolah.

\section{Pengujian Persepsi Pengguna}

Berikut hasil olah data pengujian persepsi pengguna dengan responden 6 guru pada dibidang yang bersangkutan dan 30 siswa kelas 6:

a. Aspek Tampilan

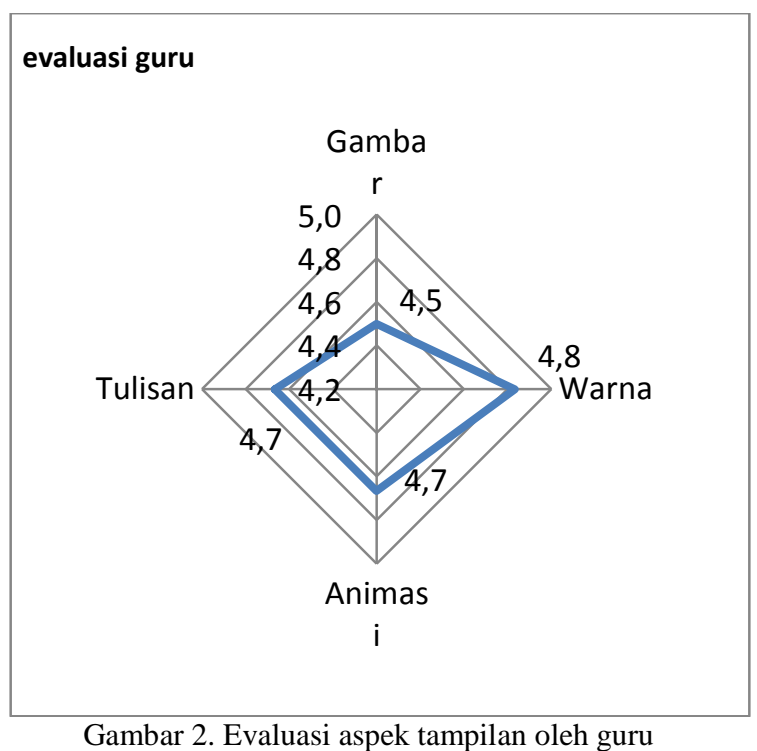

Berdasarkan gambar 2 dapat dilihat bahwa guru setuju bahwa multimedia pembelajaran memiliki warna-warna yang tidak menimbulkan kejenuhan. Guru sangat setuju bahwa multimedia pembelajaran memiliki gambar yang menarik perhatian, animasi mempermudah pemahaman materi, serta tulisan yang digunakan dapat terbaca.

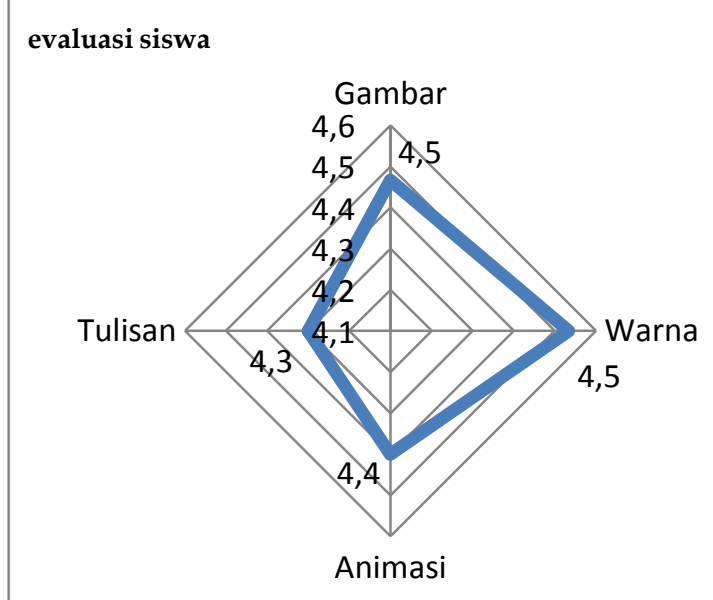

Gambar 3. Evaluasi aspek tampilan oleh siswa

Evaluasi terhadap aspek tampilan menandakan bahwa siswa setuju bahwa multimedia pembelajaran menggunakan gambar yang menarik perhatian, memiliki animasi yang mempermudah memahami materi, penggunaan warna yang tidak menimbulkan kejenuhan dan tulis-tulisan yang dapat dibaca. 
b. Aspek interaksi

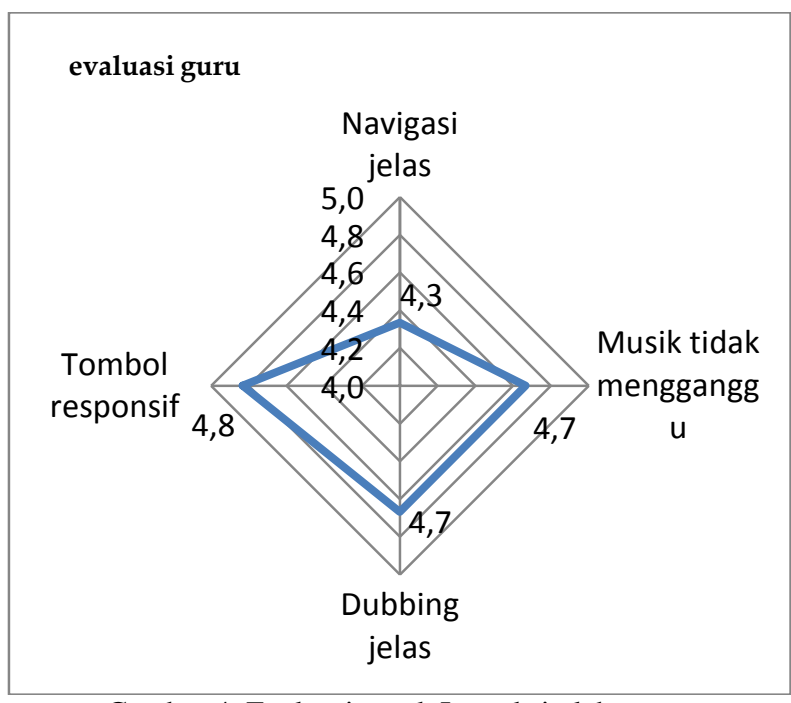

Gambar 4. Evaluasi aspek Interaksi oleh guru

Guru setuju interaksi multimedia pembelajaran memiliki navigasi yang jelas. Guru sangat setuju bahwa multimedia pembelajaran memiliki tombol responsif, musik yang tidak mengganggu konsentrasi, dan terdapat dubbing materi yang jelas.

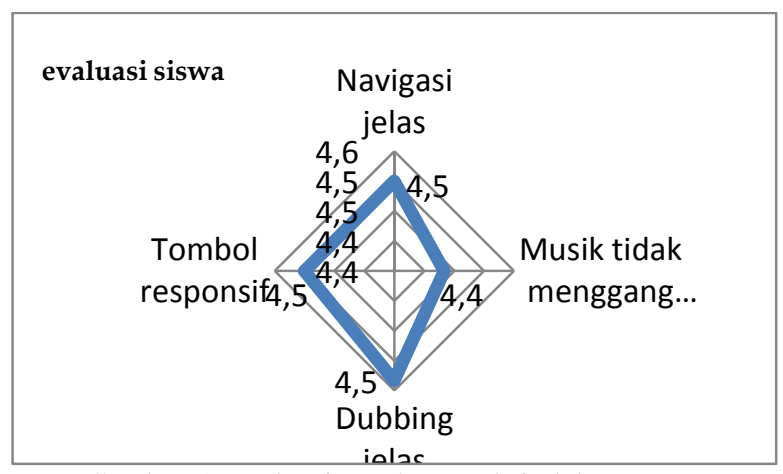

Gambar 5. Evaluasi aspek Interaksi oleh guru

Siswa setuju interaksi multimedia pembelajaran memiliki navigasi yang jelas, tombol responsif, musik yang tidak mengganggu konsentrasi, dan terdapat dubbing materi yang jelas.

c. Aspek materi

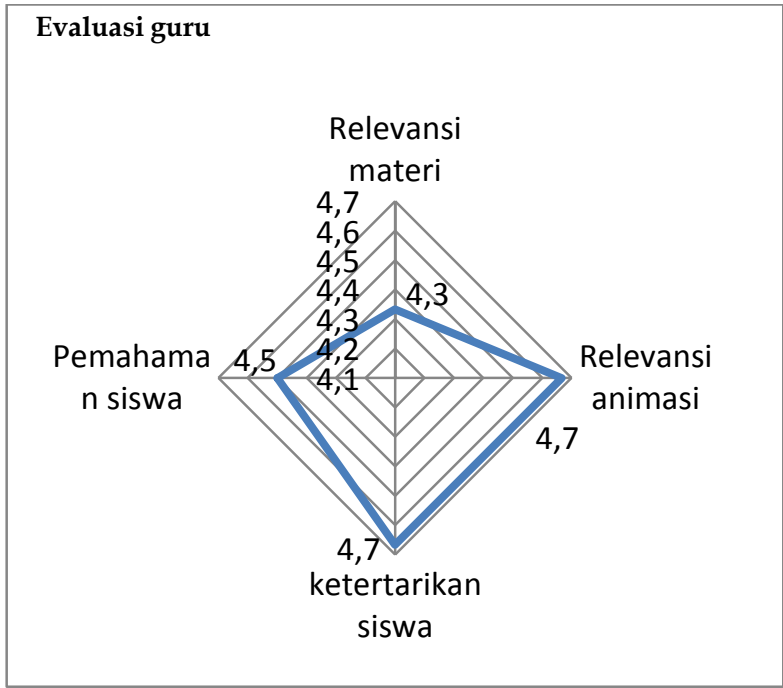

Gambar 6. Evaluasi aspek materi oleh guru

Dinilai dari aspek materi, dapat dilihat bahawa guru setuju bahwa multimedia pembelajaran memiliki relevansi materi dengan buku ajar yang digunakan, dan mampu meningkatkan pemahaman siswa. Guru Sangat setuju bahwa visualisasi perkembangbiakan hewan dan tumbuhan dalam bentuk animasi relevan dengan pokok bahasan sehingga siswa tertarik untuk belajar.

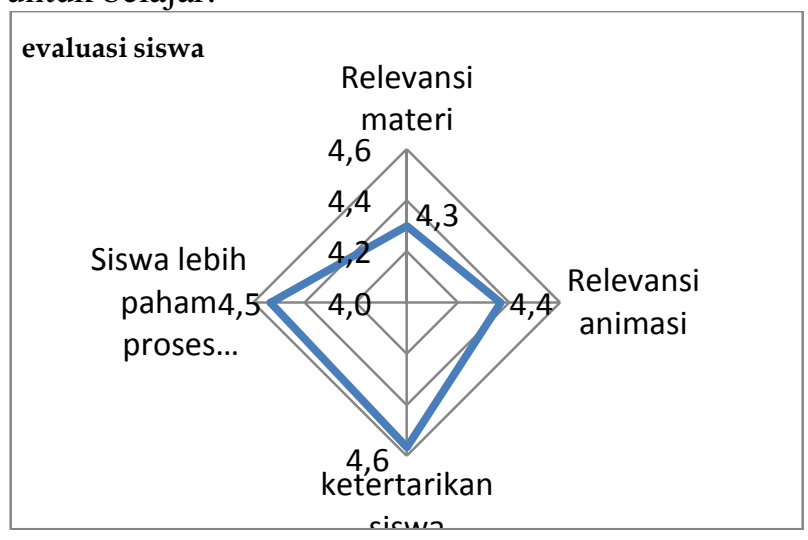

Gambar 7. Evaluasi aspek materi oleh siswa

Siswa setuju bahwa multimedia pembelajaran memiliki relevansi materi dan visualisasi perkembangbiakan hewan tumbuhan dengan buku ajar yang digunakan. Siswa juga setuju bahwa multimedia pembelajaran mampu meningkatkan pemahaman siswa. Siswa sangat setuju bahwa dengan multimedia pembelajaran sehingga siswa tertarik untuk belajar. 


\section{d. Aspek infrastruktur}

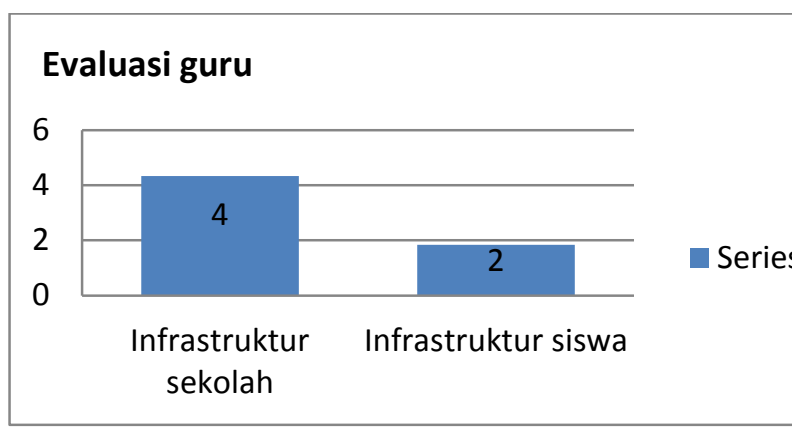

Gambar 8. Evaluasi aspek Infrastruktur oleh guru

Guru setuju bahwa sekolah sudah memiliki infrastruktur pendukung untuk menjalankan aplikasi, seperti komputer dan LCD, namun guru tidak setuju bahwa siswa sudah memiliki komputer dirumah.

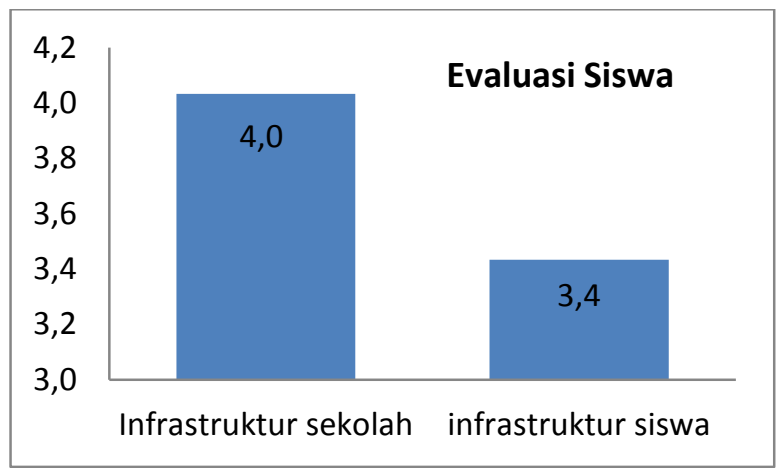

Gambar 9. Evaluasi aspek infrastruktur oleh siswa

Siswa setuju bahwa sekolah sudah memiliki infrastruktur pendukung untuk menjalankan multimedia pembelajaran dan kurang setuju bahwa siswa sudah memiliki komputer dirumah.

\section{KESIMPULAN}

Seluruh fungsionalitas multimedia pembelajaran dapat berjalan sesuai instruksi guru. Fungsionalitas aplikasi berjalan $100 \%$.

Variabel tampilan, interaksi dan materi pada multimedia pembelajaran perkembangbiakan hewan dan tumbuhan dapat diterima oleh guru dan siswa. Implementasi multimedia pembelajaran sebagai alat bantu guru dalam mendemostrasikan materi ajar sudah dapat dilakukan karena sekolah sudah memiliki Infrastruktur komputer. Namun terjadi kendala pada implementasi mandiri bagi siswa secara perseorangan. Hal ini disebabkan terdapat $40 \%$ siswa belum memiliki perangkat yang mendukung implementasi multimedia pembelajaran.

Penelitian ini dapat dilanjutkan dengan mengukur dampak penggunaan multimedia pembelajaran terhadap kesuksesan belajar siswa.

\section{UCAPAN TERIMA KASIH}

Terima kasih kepada Direktorat Riset dan Pengabdian Masyarakat-Direktorat Jendral Penguatan Ristek dan PengembanganKementrian Riset, Teknologi, dan Pendidikan Tinggi Republik Infonesia.

\section{DAFTAR PUSTAKa}

[1] A. M. Sarah K Howard, "Teacher: Technology, Change and Resistance," in Technologies: Big Issues and Critical Questions, 1st ed., G. R. Michael Henderson, Ed. Britania: Cambridge University Press, 2015, p. 307.

[2] F. Nastiti, N. Erlina, and H. E. Saputro, "The Design of Instructional Multimedia based on Vegetative and Generative Reproduction Subject for Primary School," in Research to Serve Society, 2017, pp. 191-201.

[3] G. Kneze and R. Christensen, "Extending the will, skill, tool model of technology integration: adding pedagogy as a new model construct," J. Comput. High. Educ., vol. 28, no. 3, pp. 307-325, 2016.

[4] A. Sinaga and Zainnudin, "Persepsi dan Implementasi Kebijakan Teknologi Informasi Dan Komunikasi Sebagai Sarana Pembelajaran dan Pengaruhnya Terhadap Peningkatan Kualitas Pendidikan Pada SMA Negeri Kota Pematang Siantar," J. Adm. Publik Univ. Medan Area, vol. 3 , no. 1, p. 7, 2013.

[5] A. Kirkwood and L. Prince, "Examining some assumptions and limitations of research on the effects of emerging technologies for teaching and learning in higher education," Br. J. Educ. Technol., vol. 44, no. 4, pp. 536-543, 2013.

[6] M. Heitink, J. Voogt, L. Verplanken, J. Van Braak, and P. Fisser, "Teachers' professional reasoning about their pedagogical use of technology," Comput. Educ., vol. 101, pp. 70-83, 2016.

[7] P. H. Agusditya, I. G. A. A. S. Asri, and I. Suara, "The Effect of Scientific Approach Based on Portfolio Assessment towards the Learning Outcomes of Civic Education of the Students Grade $\mathrm{V}$ Viewed from the Tendency of Observing Objects on Theme 7 SDN 4 Ubung," J. Educ. Res. Eval., vol. 1, no. 2, pp. 91-99, 2017.

[8] Palupiningdyah and Widiyanto, "Strategi Peningkatan Kualitas Pembelajaran Melalui Pemanfaatan Increasing Learning Motivation (ILMO)," Ekspansi, vol. 6, no. 2, pp. 184-194, 2011.

[9] H. Seffi, M. Julia, and R. Maria, "Emotional design in multimedia learning: Differentiation on relevant 
Jurnal Teknologi Informatika dan Terapan Vol. 04, No 02, Juli - Desember 2017

design features and their effects on emotions and learning," Comput. Hum. Behav. Elsevier, vol.

Volume 44, no. Maret, pp. 81-955, 2015. 
